\title{
Contamination of Soil Transmitted Helminths (STH) Eggs in Raw Vegetables at Street Food Stalls and Restaurant in Lorok Pakjo Village, Palembang Leo Medianto Faziqin ${ }^{1}$, Dalilah$^{2}$, Dwi Handayani ${ }^{2}$, Chairil Anwar $^{2}$, Susilawati2
}

${ }^{1}$ Medical Education Study Program, Faculty of Medicine, Universitas Sriwijaya, Palembang, Indonesia ${ }^{2}$ Parasitology Division, Faculty of Medicine, Universitas Sriwijaya, Palembang, Indonesia

\section{A R T I C L E I N F O}

Keywords:

Contamination of STH eggs

Raw vegetables

Street food stalls

Restaurant

*Corresponding author:

Dalilah

\section{E-mail address: \\ dalilah@fk.unsri.ac.id}

All authors have reviewed and approved the final version of the manuscript.

https://doi.org/10.32539/bsm.v5i6.397

\begin{abstract}
A B S T R A C T
Background: Infection Soil Transmitted Helminths (STH) is a disease that is a problem in the world, especially in areas with a tropical climate like Indonesia. This infection can be transmitted through consumption of raw vegetables contaminated with STH. This study aims to determine whether there is contamination of STH eggs in raw vegetables at street food stalls and restaurants in Lorok Pakjo Village, Palembang. Methods: This research is a descriptive observational study. Samples in the form of fresh vegetables were collected from 18 street stalls and 14 restaurants in Lorok Pakjo Village, Palembang. Samples were examined using the sedimentation method and observed using a microscope. Results: The results obtained 80 samples consisting of 30 cabbage, 18 basil, 30 cucumber, 1 lettuce, and 1 eggplant. Of the 80 samples, there were $20(25 \%)$ positive samples contaminated with STH eggs consisting of $8(10 \%)$ cabbage samples, $8(10 \%)$ basil samples, $4(5 \%)$ cucumber samples, and no STH contamination was found in lettuce. and eggplant. Of the 20 positive samples of STH contamination, 12 samples came from street vendors consisting of $5(10.6 \%)$ cabbage samples, $6(12.8 \%)$ basil samples, and $1(2.1 \%)$ cucumber samples. While the other 8 samples came from restaurants consisting of $3(9.1 \%)$ cabbage samples, $2(6 \%)$ basil samples, and $3(9.1 \%)$ cucumber samples. Found only eggs of Ascaris lumbricoides infertile decorticate in all samples consisting of 9 eggs on cabbage, 16 eggs on basil, and five eggs on cucumber. Conclusion: There is contamination of eggs Soil Transmitted Helminths in raw vegetables in street food stalls and restaurants in Lorok Pakjo Village, Palembang.
\end{abstract}

\section{Introduction}

Soil Transmitted Helminths (STH) is a group of worms whose transmission process is related to soil ${ }^{1}$. The main species that infect humans are roundworms (Ascaris lumbricoides), whipworms (Trichuris trichiura), hookworms (Necator americanus and Ancylostoma duodenale), Strogyloides stercoralis and some species Trichostrongylus ${ }^{2,3}$.

Nearly 2 billion people or about a quarter of the world's population are infected by STH. Worldwide, it is estimated that about 820 million people are infected with Ascaris lumbricoides, about 440 million people are infected with whipworms, and about 460 million people are infected with hookworms ${ }^{2}$. According to Garcia, an estimated 35 million people are infected with Strongyloides stercoralis and as many as 5.5 million people are infected with Trichostrongylus worldwide4. The prevalence of worms in Indonesia ranges from 20$86 \%$ with an average of $30 \%^{5}$. This prevalence is still very high, especially in the poor population with poor sanitation6.

Indonesian people have a habit of consuming fresh vegetables. Lalapan is a vegetable that is generally consumed in a raw (fresh) state 7 . The habit of eating raw vegetables needs to be careful, especially if the washing process is not good so it is very possible that there are still STH eggs in the vegetables ${ }^{8}$. STH 
contamination in vegetables can occur if during the planting process using contaminated water or untreated wastewater. In addition, environmental conditions such as contamination of soil and water sources with human waste, the use of feces as fertilizer greatly contribute to STH contamination of vegetables.

Lorok Pakjo village is one of 6 village in Ilir Barat I sub-district, Palembang ${ }^{10}$. This village is located in the center of Palembang and is the village with the most populous population in Ilir Barat I Subdistrict, Palembang11,12. Although the majority of the population in Lorok Pakjo has access to adequate sanitation facilities (latrines are healthy), there are still some people who do not have such access. 13

Based on the Monthly Report of Palembang City Health Office, recorded in January 2017 there were 137 cases of intestinal worms due to Trichuris trichiura, 13 cases due to worms, Ascaris lumbricoides and 2 cases of intestinal worms from hookworm 14. Several studies regarding STH infection in elementary school students, contamination of STH eggs in fresh vegetables in traditional markets, modern markets and food stalls in Palembang City still showed positive results of infection and contamination of STH eggs. This study aims to determine whether there is contamination of STH eggs in fresh vegetables at street stalls and restaurants in Lorok Pakjo Village, Palembang. with a laboratory and field approach. This research took place from July to December 2020 at street stalls and restaurants in the Lorok Pakjo Village, Palembang and observations were made at the Biooptics Laboratory and Medical Chemistry Laboratory, FK Unsri.

Samples in the form of fresh vegetables were collected from 18 street stalls and 14 restaurants in Lorok Pakjo Village, Palembang (See Figure 1.). All types of fresh vegetables provided will be collected by buying 2 food menus that are already one package with fresh vegetables. Lalapan is wrapped separately with food and each type of lalapan is also wrapped separately. Then the samples were made into preparations using the sedimentation method.

The preparation procedure was started by soaking fresh vegetables samples into $0.2 \% \mathrm{NaOH}$ solution for 30 minutes. Then set aside the fresh vegetables and soaking water for 1 hour. After that, the top of the soaking water is removed and $10-15 \mathrm{ml}$ is left and then put into the tube. Next, label the tube and centrifuge at $1500 \mathrm{rpm}$ for 5 minutes. The top solution was discarded and the precipitate remained. Take one drop of sediment using a dropper, then drop it on the object glass. Then add one drop of $1 \%$ eosin using a dropper and cover with a cover glass and die using a microscope.

\section{Method}

This research is a descriptive observational study

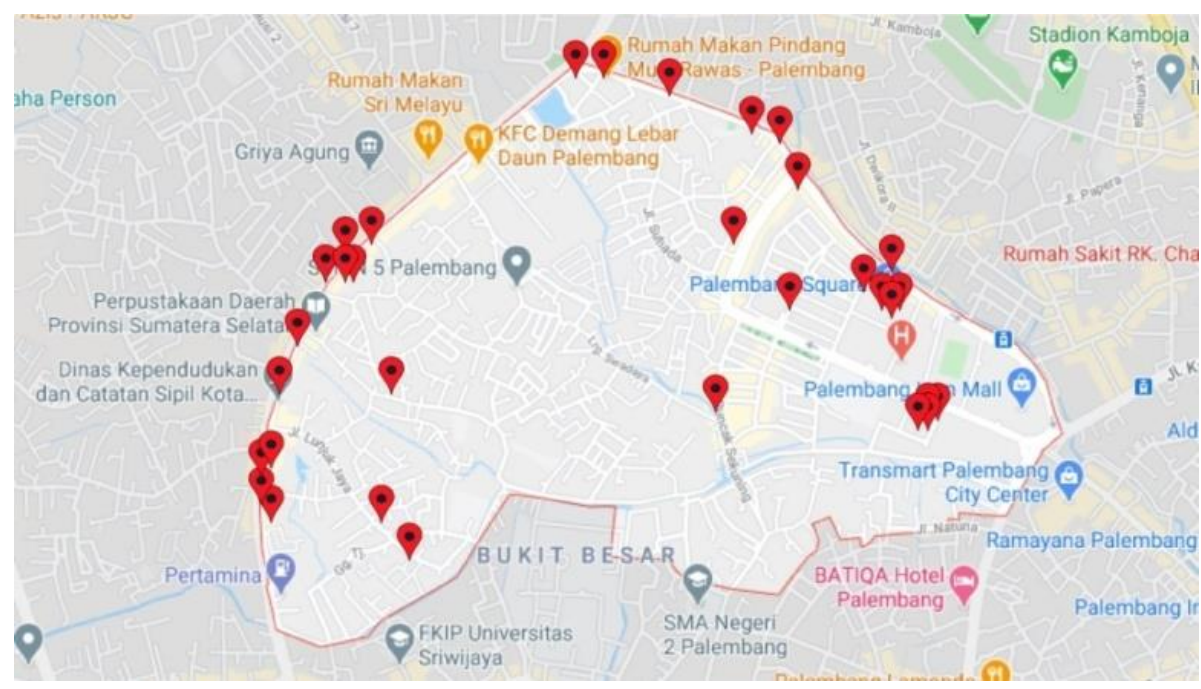

Figure 1. Map of the location of street food stalls and restaurants where raw vegetables were sampled in Lorok Pakjo Village, Palembang. 


\section{Results}

The sample of raw vegetables in this study was taken from 32 locations, consisting of 18 street food stalls and 14 restaurants in Lorok Pakjo Village, Palembang. The total number of samples obtained were 80 raw vegetables samples. Based on data from observations made at the Biooptics Laboratory and Medical Chemistry Laboratory, FK Unsri, from 80 samples found there were 20 positive samples contaminated with STH eggs and 60 other samples showing negative results.

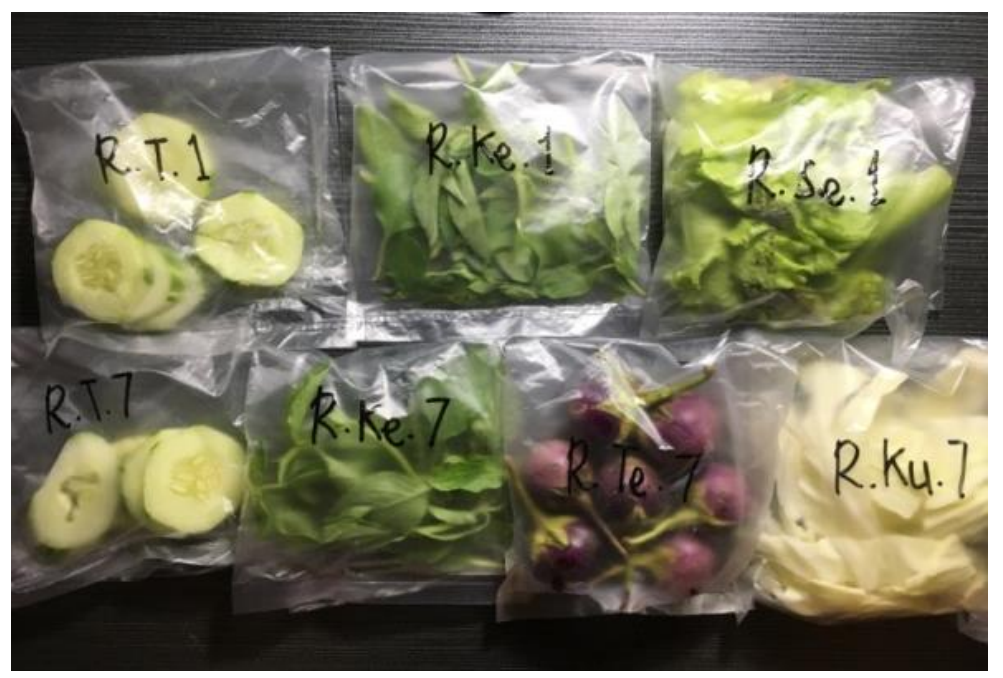

Figure 2. Types of raw vegetables served at street food stalls and restaurants in Lorok Pakjo Village, Palembang.

Table 1. Types of raw vegetables provided at street food stalls and restaurants in Lorok Pakjo, Palembang.

\begin{tabular}{cccc}
\hline & \multicolumn{3}{c}{ Locations } \\
Types of raw & \multicolumn{2}{c}{ Total } \\
\cline { 2 - 4 } vegetables & Street food stalls & Restaurants & \\
\hline Cabbage & 18 & 12 & 30 \\
Basil & 12 & 6 & 18 \\
Cucumber & 17 & 13 & 30 \\
Lettuce & 0 & 1 & 1 \\
Eggplant & 0 & 1 & 1 \\
\hline Total & 47 & 33 & 80 \\
\hline
\end{tabular}

Table 1. shows the number of samples and types of raw vegetables provided in street food stalls and restaurants in Lorok Pakjo Village, Palembang which consisted of 30 samples of cabbage, 18 samples of basil, 30 samples of cucumber, 1 sample of lettuce, and 1 sample of eggplant.
From 80 samples there were 20 (25\%) positive samples contaminated with STH eggs. In the cabbage salad, eight (10\%) samples were positive for STH eggs, five from street stalls and three samples from restaurants. There were eight (10\%) samples of basil vegetables, six from street stalls and two from restaurants. There were four $(5 \%)$ samples of cucumber 
Table 2. Distribution of STH egg contamination frequency in raw vegetables at street food stalls

\begin{tabular}{llll}
\hline \multicolumn{1}{c}{$\begin{array}{c}\text { Types of } \\
\text { Vegetables }\end{array}$} & Total (n) & $\begin{array}{c}\text { Number of } \\
\text { Positives }\end{array}$ & Frequency (\%) \\
\hline Cabbage & & & $10.6 \%$ \\
Basil & 18 & 5 & $12.8 \%$ \\
Cucumber & 12 & 6 & $2.1 \%$ \\
Lettuce & 17 & 1 & 0 \\
Eggplant & 0 & 0 & 0 \\
& 0 & 0 & \\
\hline Total & 47 & 12 & $25.5 \%$ \\
\hline
\end{tabular}

Table 2, showed that contamination of STH eggs in raw vegetables at street food stalls was $12(25.5 \%)$ samples consisting of $5(10.6 \%)$ cabbage samples, 6 (12.8\%) basil samples, and 1 cucumber $(2,1 \%)$ sample.

Table 3. Distribution of STH Egg Contamination Frequency in raw vegetables in Restaurants

\begin{tabular}{cccc}
\hline $\begin{array}{c}\text { Types of } \\
\text { Vegetables }\end{array}$ & Total (n) & $\begin{array}{c}\text { Number of } \\
\text { Positives }\end{array}$ & Frequency (\%) \\
\hline Cabbage & 12 & 3 & $9.1 \%$ \\
Basil & 6 & 2 & $6 \%$ \\
Cucumber & 13 & 3 & $9.1 \%$ \\
Lettuce & 1 & 0 & $0 \%$ \\
Eggplant & 1 & 0 & $0 \%$ \\
& & 8 & \\
\hline Total & 33 & & \\
\hline
\end{tabular}

Table 3 showed that the contamination of STH eggs in fresh vegetables in restaurants was 8 (24.2\%) samples consisting of $3(9.1 \%)$ cabbage samples, 2 (6\%) basil samples, 3 (9.1\%) cucumber samples, and no STH egg contamination was found in lettuce and eggplant.

\section{Identification of STH nematode eggs}

There were 20 positive samples contaminated with STH intestinal nematode eggs with only one species of STH found, namely Ascaris lumbricoides infertile decorticate. The results of microscopic observations of STH eggs can be seen in Figure 3.

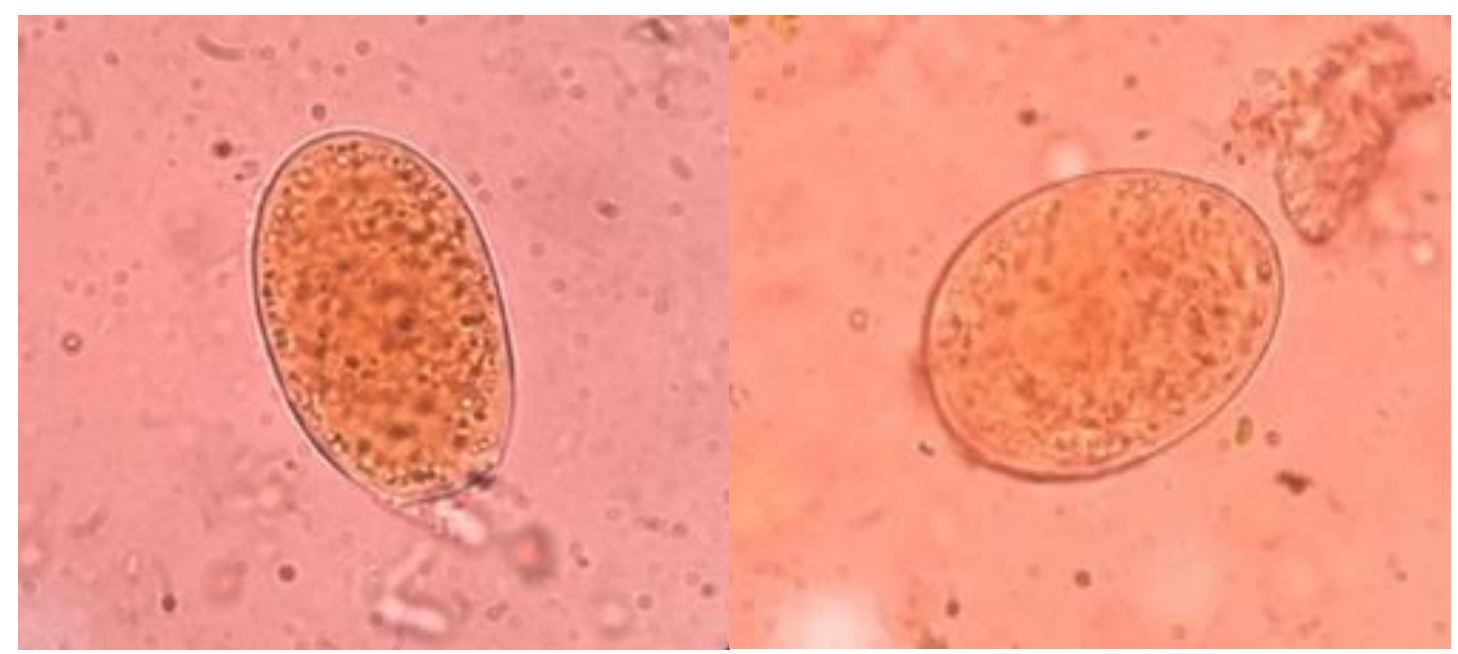

Figure 3. Eggs of Ascaris lumbricoides infertile decorated with 100x magnification 
Table 4. Number of STH eggs in street food stalls and restaurants

\begin{tabular}{cccc}
\hline Types of raw & \multicolumn{2}{c}{ Locations } & Total \\
\cline { 2 - 3 } vegetables & $\begin{array}{c}\text { Street food } \\
\text { stalls }\end{array}$ & Restaurants & \\
\hline Cabbage & 5 & 4 & 9 \\
Basil & 10 & 6 & 16 \\
Cucumber & 2 & 3 & 5 \\
Lettuce & 0 & 0 & 0 \\
Eggplant & 0 & 0 & 0 \\
\hline Total & 17 & 13 & 30 \\
\hline
\end{tabular}

In Table 6. The number of STH eggs found were 30 eggs consisting of 17 eggs were found in raw vegetables sample from the street food stall and 13 eggs were found in the raw vegetables sample from the restaurant. The highest number of eggs found in basil was 16 eggs, cabbage 9 eggs, and cucumber 5 eggs.

\section{Discussion}

This study consisted of 80 samples of raw vegetables taken from 32 different locations, namely 18 street food stalls and 14 restaurants in Lorok Pakjo Village, Palembang. Sampling of raw vegetables was done once for 2 weeks. The types of raw vegetables obtained consisted of 30 samples of cabbage, 18 samples of basil, 30 samples of cucumber, 1 sample of lettuce, and 1 sample of eggplant.

In this study, 20 (25\%) samples were positively contaminated with STH eggs from a total of 80 fresh vegetables samples. From 20 samples that were positively contaminated with STH, 12 (15\%) samples came from street vendors and 8 (10\%) other samples came from restaurants. The results of this study according to some studies that have been done before, such research has been carried out by Astria on vegetables offered at street food stalls around FK Unsri Campus Madang and RSMH Palembang get sth positive contamination $33.3 \%$ of 45 samples of vegetables. ${ }^{15}$ The results of this study are also in accordance with the research conducted by Mutiara on raw vegetables sold in canteens around the University of Lampung. Of the 19 canteen or food stalls around the University of Lampung, found contamination STH 4 (21.1\%) samples. 16
Based on the type of raw vegetables, STH egg contamination in cabbage vegetables was $10 \%$, basil was $10 \%$, cucumber was $5 \%$, and no STH contamination was found in lettuce and eggplant vegetables. Based on location, STH egg contamination in raw vegetables at street food stalls was $10.6 \%$ in cabbage vegetables, $12.8 \%$ in basil, and $2.1 \%$ in cucumbers. Meanwhile, STH egg contamination in raw vegetables in restaurants was $9.1 \%$ in cabbage, $6 \%$ in basil, $9.1 \%$ in cucumber, and no STH egg contamination was found in lettuce and eggplant vegetables. The results of STH egg contamination in cabbage were in accordance with the research conducted by Alfiani et al. at the Simpang Lima food court in Semarang which got the results of contamination of STH eggs as much as $54.5 \% 17$. The results of STH egg contamination in basil in this study were also the same as those conducted by Lobo et al. on fresh basil grilled fish sellers in Palu with 39.8\% STH egg contamination results ${ }^{8}$. There are differences in the results of STH egg contamination in fresh cucumbers. Research conducted by Nasution on cucumber complementary to chicken penyet in Medan Teladan and Setiawan sub-districts on cucumber in a street food stall in Makassar City found that there was no STH egg contamination in cucumber 18,19 . Differences in the results of STH egg contamination were also found in lettuce. Prameswarie et al. get the results that there is STH contamination in lettuce vegetables sold in food stalls in Seberang Ulu II Palembang District as much as $65 \% 20$. There is no STH egg contamination in lettuce and eggplant. This can be caused by good hygiene and sanitation of the seller's food, such as washing hands before processing fresh vegetables, choosing good and 
fresh vegetables, good processing of fresh vegetables by removing some of the outer layers of fresh vegetables and washing fresh vegetables. before serving so that the fresh vegetables sold at that location are clean ${ }^{19.21}$.

STH egg contamination in fresh vegetables can occur due to poor hygiene associated with the process of growing, harvesting, packing, transporting, and storing vegetables ${ }^{22}$. Environmental factors such as climate, geography, temperature, soil type, and rainfall also play an important role that contributes to the prevalence of parasitic infections ${ }^{23}$. In addition, the morphology of fresh vegetables also plays a role in the possibility of STH contamination ${ }^{18}$. In this study, STH egg contamination was most commonly found in cabbage and basil vegetables. This is probably due to the fact that cabbage and basil have short stems so that the leaves are close to the soil surface and have very curved and uneven leaf surfaces so that worm eggs are easy to stick and difficult to clean 16,24. Contamination of STH eggs can occur during the pre-harvest handling process such as planting using organic fertilizers from livestock or human waste, irrigation using wastewater that is not treated adequately, and vegetable growing land can also be a source of STH transmission because the soil is loose and moist for cultivation. Planting vegetables is a very suitable medium for the development of worms considering that there is still a habit of defecation in the garden soil (in certain areas) $)^{9,25}$.

While in the process of post-harvest handling, contamination may occur during the process of storage and distribution of unhygienic 26 .It is better to wash fresh vegetables before storing so they are not contaminated with STH and do not cause crosscontamination with other vegetables. In addition, the storage of raw vegetables are not clean and moist, allowing STH eggs to survive and develop into the infective form 27.STH eggs can survive at low temperatures, so storing fresh vegetables in the refrigerator will not remove or damage STH eggs 28 .

Poor hygiene during the sales process, preparation, and consumption is also contributing role in STH contamination in vegetables ${ }^{26}$. Good vegetable washing technique is to rinse each piece leaves under running water, after which it can be done soaking vegetables in water with a little salt so that the remaining dirt and small animal veterinary attached to the leaf could be dead andmissing. ${ }^{29}$ Before serving food, sellers should wash their hands with soap and running water and use assistive devices (gloves/food tongs) to reduce the possibility of contamination 15,30.

The type of STH eggs found in this study was only eggs decorated Ascaris lumbricoides infertile. These results are consistent with a study conducted by Astria which contained only eggs Ascaris lumbricoides infertile ${ }^{15}$. Adrianto also found the same result, namely only eggs were found Ascaris spp 32 . The same result was also found by Pradiastuti that only eggs were found Ascaris lumbricoides decorticated ${ }^{31}$. Infertile eggs (eggs that are not fertilized) are not harmful to the body because these eggs will not cause infection if ingested ${ }^{33}$. Only Eggs were found, Ascaris lumbricoides this could be due to the nature of eggs Ascaris lumbricoides which survive in the soil at freezing temperatures which are usually found in winter ${ }^{8}$.eggs Ascaris lumbricoides can survive at temperatures $<8^{\circ} \mathrm{C}$ but eggs Trichuris trichiura will spoil at these temperatures ${ }^{28}$.eggs Ascaris lumbricoides are also resistant to chemical disinfectants and to temporary immersion in harsh chemicals. In addition, eggs can also live for months in sewer water and feces 8 . Mature eggs of Ascaris lumbricoides can generally survive for several years in cold, hot, or dry weather, whereas hookworms can only survive for about 7-8 weeks ${ }^{34}$.

Different results in the study conducted by Alsakina et al. that there are variations in the contamination of STH eggs, namely contamination due to Ascaris lumbricoides as much as $34.1 \%$, theneggs Trichuris trichiura and hookworms each by $1.58 \% 35$. Variations were also found in the research conducted by Nasution, namely contamination of eggs Ascaris lumbricoides as much as $14.7 \%$, while eggseggs Trichuris trichiura as much as $3.4 \%$ and hookworm as much as $1.1 \% 18$. Varied types of eggs were also found in the study conducted by Alfiani et al., namely the contamination of eggs Ascaris lumbricoides as much as 27.3\%, eggs Trichuris trichiura as much as $18.2 \%$, and hookworm eggs as much as $9.1 \% 17$. 
The number of STH eggs found from 20 samples of raw vegetables that were positively contaminated with STH eggs in this study were 30eggs Ascaris lumbricoides. The highest number of eggs found in fresh basil was 16 eggs, cabbage salad 9 eggs, and cucumber 5 eggs. The number of STH eggs found in each sample varied from 1 to $4 \mathrm{STH}$ eggs. The results of this study can be compared with research conducted by Astria on fresh vegetables provided in food stalls around FK Unsri Madang and RSMH Palembang. Of the 45 samples collected, 15 samples were found to be contaminated with STH eggs with the number of STH eggs found as many as 30eggs Ascaris lumbricoides ${ }^{15}$. The results with fewer STH eggs were found in a study conducted by Pradiastuti on watercress, cabbage, and basil in Sekip Traditional Market and PTC Palembang Modern Market. From a total of 41 samples collected, there were 9 samples from Sekip Traditional Market contaminated with STH eggs with 12 eggs of Ascaris lumbricoides and 6 samples from Modern Market PTC Palembang contaminated with STH eggs with 7 eggs of Ascaris lumbricoides 31 .

\section{Conclusion}

Based on the results of research that has been carried out regarding the contamination of eggs Soil Transmitted Helminths (STH) in raw vegetables at street food stalls and restaurants in Lorok Pakjo Village, Palembang, it can be concluded that there are 80 samples of raw vegetables that have been collected from 18 street food stalls and 14 restaurants in Palembang. Lorok Pakjo Village, Palembang. The types of raw vegetables obtained consisted of 30 samples of cabbage, 18 samples of basil, 30 samples of cucumber, 1 sample of lettuce, and 1 sample of eggplant. Of the total 80 samples that have been collected, there were $20(25 \%)$ positive samples contaminated with STH eggs with positive results of STH eggs on cabbage vegetables as many as $8(10 \%)$ samples, 8 (10\%) basil samples, 4 (5\%) cucumbers) samples, and no STH contamination was found in lettuce and eggplant. STH egg type found only eggs of Ascaris lumbricoides infertile decorticated. The number of STH eggs found from 20 raw vegetables samples that were positively contaminated with STH eggs in this study were 30 eggs Ascaris lumbricoides. The number of STH eggs found in each sample varied from 1 to 4 STH eggs.

\section{Acknowledgment}

The authors would like to thank dr. Dalilah, M. Case. and dr. Dwi Handayani, M. Kes. as a supervisor who has directed, provided knowledge, support, and motivation, and has provided time to guide the author in completing this thesis. Thanks to Prof. dr. H. Chairil Anwar, DAP\&E, Ph.D, Sp.ParK. and dr. Susilawati, M.Kes. as examiners who have provided input, criticism, and suggestions for improvement in completing this thesis. Thanks to dr. Riana Sari Puspita Rasyid, M. Biomed. as the Head of the Biooptics Laboratory of FK Unsri, Mrs. Fatmawati, S.Si, MSi. as the Head of the Laboratory of Biochemistry and Medical Chemistry, FK Unsri, who has helped the author during the research and preparation of this thesis.

\section{References}

1. Natadisastra D, Agoes R. Parasitologi Kedokteran: Ditinjau dari Organ yang Diserang. Jakarta: Penerbit Buku Kedokteran EGC. 2005; 72-80.

2. World Health Organization. Guideline: Preventive Chemotherapy to Control SoilTransmitted Helminth Infections in at-Risk Population Groups [Internet]. WHO Press. 2017.

3. Sutanto I, Ismid IS, Sjarifuddin PK, Sungkar S. Buku Ajar Parasitologi Kedokteran Edisi Keempat. Jakarta: Badan Penerbit FKUI. 2008.

4. Garcia LS. Diagnostic Medical Parasitology 6th Edition. Washington DC, USA: American Society for Microbiology Press. 2016.

5. Direktorat Jenderal Pencegahan dan Pengendalian Penyakit. Rencana Aksi Program Pencegahan dan Pengendalian Penyakit 20152019 (Revisi I - 2018) [Internet]. Jakarta; 2018.

6. Indonesia KKR. Peraturan Menteri Kesehatan RI Nomor 15 Tahun 2017 Tentang Penanggulangan Cacingan [Internet]. Jakarta: 
Kemenkes RI; 2017.

7. AH.A. Tingkat Kebiasaan Makan Lalapan Masyarakat Sunda, Hubungannya dengan Asupan dan Kadar $\beta$-Karoten, serta Persepsi Kualitas Kulit [Internet]. Institut Pertanian Bogor; 2019.

8. Lobo LT. L, J. W, Octaviani, Puryadi. Kontaminasi Telur Cacing Soil-transmitted Helminths (STH) pada Sayur Kemangi Pedagang Ikan Bakar di Kota Palu Sulawesi Tengah. Media Litbangkes [Internet]. 2016;26(2): 65-70.

9. AJ.D, JR.W,T.T, Diya AW. Public Health Significance of Helminthes Eggs Isolated from Raw Vegetables Obtained from Farms and those Sold within Kaduna Metropolis Nigeria. Asian J Microbiol Biotechnol Environ Sci [Internet]. 2015; 17(3): 527-32.

10. Peraturan Daerah Kota Palembang Nomor 15 Tahun 2012 tentang Rencana Tata Ruang Wilayah Kota Palembang Tahun 2012-2032 [Internet].

11. Yuliani. Pengaruh Tayangan Halo Palembang PALTV terhadap Minat Masyarakat Kelurahan Lorok Pakjo RT.50 RW.14 Kecamatan Ilir Barat I Bukit Besar tentang Konten Budaya Lokal [Internet]. UIN Raden Fatah; 2019.

12. BPS Kota Palembang. Kecamatan Ilir Barat I Dalam Angka [Internet]. Palembang; 2019.

13. Dinkes Kota Palembang. Profil Kesehatan Tahun 2017 [Internet]. Palembang; 2017.

14. Dinkes Kota Palembang. Laporan Bulanan Januari 2017 [Internet]. Palembang; 2017.

15. Astria F. Identifikasi Telur Soil Transmitted Helminths pada Lalapan yang Disediakan di Warung Makan sekitar Fakultas Kedokteran UNSRI Kampus Madang dan RSMH Palembang. Universitas Sriwijaya; 2017.

16. Mutiara H. Identifikasi Kontaminasi Telur Soil Transmitted Helminths pada Makanan Berbahan Sayuran Mentah yang Dijajakan Kantin Sekitar Kampus Universitas Lampung Bandar Lampung. J Kedokt Unila. 2015; 5(9): 29-32.
17. Alfiani U, Sulistiyani, Ginandjar P. Hubungan Higiene Personal Pedagang Dan Sanitasi Makanan Dengan Keberadaan Telur Cacing Soil Transmitted Helminths (STH) pada Lalapan Penyetan di Pujasera Simpanglima Kota Semarang. J Kesehat Masy [Internet]. 2018; 6(1): 685-95.

18. Nasution AK. Kontaminasi Telur Soil Transmitted Helminths (STH) pada Sayuran Mentah Pelengkap Ayam Penyet di Kecamatan Medan Teladan [Internet]. Universitas Muhammadiyah Sumatera Utara; 2018.

19. Setiawan A, Indrawati A, Syarif J. Identifikasi Telur Soil Transmitted Helminths pada Lalapan Mentimun di Warung Makan Jalan Abdul Kadir Kota Makassar. J Med Laboran [Internet]. 2017; 7(2): 16-21.

20. Prameswarie T, Ghiffari A, Z.A. I, Prameswari M. Dua Spesies Cacing Soil Transmitted Helminths pada Sayuran Selada (Lactuca sativa) yang Dijual di Warung Makan pada Kecamatan Seberang Ulu II Palembang. Sriwij J Med [Internet]. 2019; 2(3): 159-63.

21. Safitri R, Kurniawan B, Kurniawaty E. Identifikasi Kontaminasi Telur Soil Transmitted Helminths (STH) pada Lalapan Kubis (Brassica oleracea) di Warung Makan Kaki Lima Sepanjang Jalan Zainal Abidin Pagar Alam Kota Bandar Lampung. Majority [Internet]. 2019; 8(2).

22. Bekele F, Tefera T, Biresaw G, Yohannes T. Parasitic Contamination of Raw Vegetables and Fruits Collected from Selected Local Markets in Arba Minch Town Southern Ethiopia. Infect Dis Poverty [Internet]. 2017; 6(1): 1-7.

23. Punsawad C, Phasuk N, Thongtup K, Nagavirochana S, Viriyavejakul P. Prevalence of Parasitic Contamination of Raw Vegetables in Nakhon Si Thammarat Province Southern Thailand. BMC Public Health. 2019;19(34): 17.

24. Said DES. Detection of Parasites in Commonly Consumed Raw Vegetables. Alexandria J Med [Internet]. 2012; 48(4): 345-52. 
25. Adrianto H. Kontaminasi Telur Cacing pada Sayur dan Upaya Pencegahannya. Balaba J Litbang Pengendali Penyakit Bersumber Binatang Banjarnegara. 2017; 13(2): 105-14.

26. Alemu G, Mama M, Misker D, Haftu D. Parasitic contamination of vegetables marketed in Arba Minch town, southern Ethiopia. BMC Infect Dis. 2019; 19(1): 1-7.

27. Muyassaroh S, Rahayu A, Wulandari M. Pengaruh Frekuensi Pencucian Pada Daun Kubis (Brassica oleracea var Capitata) Terhadap Jumlah Cacing Usus (Nematoda Intestinal). Univ Muhammadiyah Semarang Semarang. 2012; 30.

28. Siskhawahy. Pengaruh Lama Perebusan Terhadap Keutuhan Telur Ascaris lumbricoides. Universitas Muhammadiyah Semarang; 2010.

29. Wayansari L, Anwae IZ, Amri Z. Bahan Ajar Gizi: Manajemen Sistem Penyelenggaraan Makanan Institusi [Internet]. Jakarta: Badan Pengembangan dan Pemberdayaan Sumber Daya Manusia Kesehatan. Kemenkes RI.; 2018.

30. Sihombing W. Hubungan Perilaku Pramusaji Tentang Higiene Lalapan dengan Keberadaan Soil Transmitted Helminths pada Lalapan di Warung Makan di Jalan Dr Mansyur dan
Setiabudi Medan Tahun 2016 [Internet]. Universitas Sumatera Utara; 2017.

31. Pradiastuti A. Distribusi Frekuensi Soil Transmitted Helminths pada Sayur Selada Air, Kubis, dan Kemangi yang Dijual di Pasar Tradisional Sekip dan Pasar Modern Palembang Trade Center di Kota Palembang. Universitas Sriwijaya; 2016.

32. Adrianto H. Kontaminasi Telur Soil Transmitted Helminths pada Sayur Selada (Lactuca sativa) di Pasar Tradisional. Jurnak Kedokt Brawijaya [Internet]. 2018;30(2):163-7.

33. Centers for Disease Control and Prevention. DPDx-Laboratory Identification of Parasites of Public Health Concern : Ascariasis [Internet]. 2019.

34. Nadzirah bt. Mohd Pauzi NZ, Majawati ES. Perbedaan Jumlah Telur Cacing Usus pada Selada (Lactuta sativa) yang Segar dan yang Disimpan selama Satu Minggu di Lemari Es. J Kedokt Meditek. 2018; 24(67): 5-10.

35. Alsakina N, Adrial, Afriani N. Identifikasi Telur Cacing Soil Transmitted Helminths pada Sayuran Selada (Lactuca Sativa) yang Dijual oleh Pedagang Makanan di Sepanjang Jalan Perintis Kemerdekaan Kota Padang. J Kesehat Andalas. 2018; 7(3). 